Chattaway, F. W., Thompson, C. C. \& Barlow, A. J. E. (1960). J. gen. Microbiol. 22, 649-656

\title{
Carbohydrate Metabolism in Microsporum canis
}

\author{
By F. W. CHATTAWAY, C. C. THOMPSON* \\ Department of Biochemistry, School of Medicine, Leeds \\ AND A. J. E. BARLOW \\ Department of Dermatology, Huddersfield Royal Infirmary
}

SUMMARY: Examination of mycelial extracts of the dermatophyte Microsporum canis indicated the presence of most of the enzymes of the Embden-Meyerhof and hexosemonophosphate pathways of carbohydrate metabolism, and those of the tricarboxylic acid cycle.

Enzyme systems concerned in the breakdown of carbohydrates by dermatophytes have been little studied, the principal contribution being a study of a number of enzymes of the glycolytic and hexosemonophosphate pathways and of the tricarboxylic acid cycle in cell-free extracts of Trichophyton mentagrophytes (Jensen, Altschuller \& Bard, 1957). The effect of different substrates and $\mathbf{p H}$ values on the respiratory activity of agar cultures of a number of dermatophytes and of submerged cultures of Microsporum canis have also been studied (Nickerson \& Chadwick, 1946; Melton, 1951).

From studies of the action of inhibitors on intact mycelium and of the oxidation of tricarboxylic acid cycle intermediates by mycelial dispersions of Microsporum canis we obtained preliminary evidence for the presence of some of the enzymes concerned in this pathway (Chattaway, Thompson \& Barlow, 1954, 1956). The present paper describes the demonstration in cell-free extracts of a number of these enzymes, together with many of those of the glycolytic and hexosemonophosphate pathways.

\section{METHODS}

Maintenance and growth of organism. The organism was a strain of Microsporum canis Bodin originally isolated from a patient and maintained during the past 6 years by monthly subculture on a $1 \%(w / v)$ Difco proteose-peptone agar medium. Aerial mycelium from such a culture was added to a $4 \%(\mathrm{w} / \mathrm{v})$ maltose $+1 \%(w / v)$ Difco proteose-peptone liquid medium ( $\mathrm{pH} \mathrm{5 \cdot 6)}$ and incubated at $20^{\circ}$ until a mycelial pad formed; this was then washed aseptically several times with water by decantation, suspended in sterile distilled water and homogenized for 30 sec. in a stainless steel homogenizer (Moore \& Mason, 1951). One $\mathrm{ml}$. of such an homogenate was used as the inoculum in experimental cultures. These were grown as stationary cultures in $250 \mathrm{ml}$. conical flasks containing $20 \mathrm{ml}$. medium and were incubated at $20^{\circ}$.

* Present address: The Brewing Industry Research Foundation, Nutfield, Redhill, Surrey. 
Preparation of cell-free extracts. Cultures were grown for 6-8 days and the mycelial pads filtered on a Buchner funnel and well washed with water. The mycelial mass was then ground with acid-washed powdered glass (British Drug Houses Ltd.) for 10 min., during which time buffer or water was added at intervals until a smooth suspension was obtained. Alternatively, when preservation of the mycelium for a few days was desired, it was freeze-dried after washing, powdered and stored at $0^{\circ}$ and the powder ground with buffer or water immediately before use. Some deterioration occurred on keeping and fresh extracts were used whenever possible. The whole procedure was carried out at $4^{\circ}$. Glass powder and cell debris were removed by centrifugation at $2000 \mathrm{~g}$ for $10 \mathrm{~min}$. at $0^{\circ}$; further clarification of the extract was obtained when required by centrifugation at $16,500 \mathrm{~g}$ for $30 \mathrm{~min}$.

Determination of enzyme activities. Malic dehydrogenase was determined by the method of Straub (1942). Other dehydrogenases were determined by following the reduction of diphosphopyridine nucleotide (DPN) or triphosphopyridine nucleotide (TPN); reduction was shown by the change in optical density at $340 \mathrm{~m} \mu$ as measured in a Unicam SP 500 spectrophotometer with $1 \mathrm{~cm}$. quartz cuvettes at $20^{\circ}$; all values recorded were corrected for background absorption. Glucokinase activity was similarly measured by following TPN reduction in the presence of glucose and adenosine triphosphate (ATP) and phosphoglucomutase by TPN reduction in the presence of glucose-1-phosphate. Phosphohexo-isomerase was demonstrated using the method of Slein (1955), aldolase by the method of Sibley \& Lehninger (1949), aconitase and fumarase by the methods of Racker (1950). Phosphoglyceromutase, enolase and pyruvic phosphokinase were determined at the same time as described by $\mathrm{Sih} \& \mathrm{Knight}$ (1956). Succinoxidase activity was determined by conventional Warburg techniques.

Analytical methods. Pentose was estimated by the method of Mejbaum (1939), pyruvate by the method of Friedmann \& Haugen (1943), total nitrogen by the method of Markham (1942).

Chemicals. All chemicals used were of commercial origin. Barium salts were converted to sodium salts by shaking with Dowex 50 followed by neutralization with sodium hydroxide. Crystalline aldolase was obtained from Sigma Chemical Co. (St Louis, Missouri, U.S.A.).

\section{RESULTS}

\section{Enzymes of the Embden-Meyerhof pathway}

The presence of glucokinase and phosphoglucomutase in the mycelial extracts was shown by making use of the presence of an active glucose-6-phosphate dehydrogenase and following glucose-6-phosphate formation from glucose or glucose-1-phosphate by the ensuing reduction of TPN. Hexokinase activity was highest when mycelium was extracted with $0.01 \mathrm{M}$-acetate buffer ( $\mathrm{pH} \mathrm{6.4)}$; an aqueous extract was used to study the phosphoglucomutase. Typical results for glucokinase activity, together with its dependence upon the presence of ATP and magnesium, are shown in Fig. 1. A high rate of endogenous reduction 
of TPN in absence of substrates is seen; this was not significantly decreased by dialysis of the cell extract for $18 \mathrm{hr}$. against acetate buffer ( $\mathrm{pH} \mathrm{6.4)}$ at $0^{\circ}$. Typical results for phosphoglucomutase are shown in Fig. 2.

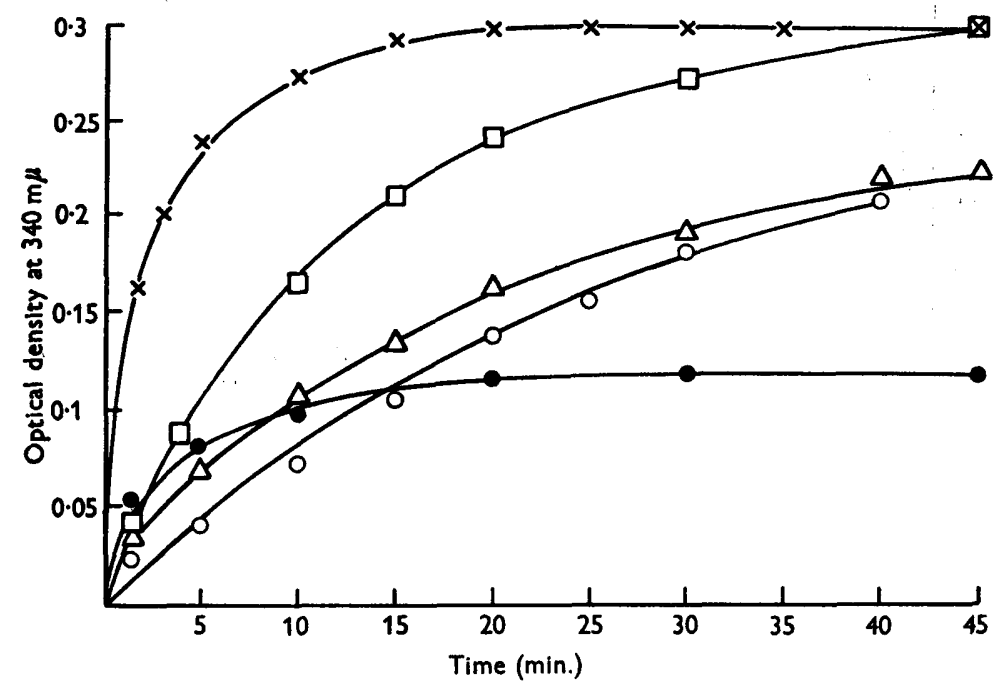

Fig. 1. Glucokinase activity. Additions : $3 \mathrm{ml}$. enzyme extract $(146 \mu \mathrm{g} . \mathrm{N} / \mathrm{ml}$.) in $0.01 \mathrm{M}$ -

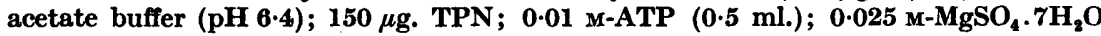
(0.1 ml.); 0.01 M-glucose (0.1 ml.); 0.01 M-glucose-6-phosphate (0.1 ml.); water to $3.8 \mathrm{ml}$. The TPN was added at zero time. Glucose substrate: $\square=$ complete system; $\Delta=$ no substrate; $O=$ no $M g$; $O=$ no ATP. Substrate glucose-6-phosphate; $x=$ complete system.

Phosphohexoisomerase activity was apparent on incubation of the enzyme extract with glucose-6-phosphate for 5 min. and was measured by the intensity of colour developed with resorcinol. Endogenous activity was of a low order and no colour was given on omission of the enzyme extract or with boiled extract.

Aldolase activity was shown by using fructose-1:6-diphosphate as substrate and incubating for $30 \mathrm{~min}$. at $35^{\circ}$; activity was proportional to enzyme concentration.

Phosphofructokinase activity was sought on a number of occasions both directly and by using glucose-6-phosphate as a substrate for aldolase; but no activity was found. Glyceraldehyde-3-phosphate dehydrogenase was studied by using fructose-1, 6-diphosphate as substrate and incubating for $\mathbf{3 0} \mathrm{min}$. with crystalline aldolase before measuring DPN or TPN reduction. The enzyme was found to be DPN specific and dependent upon the presence of arsenate or phosphate and cysteine for activity (Fig. 3).

Pyruvic acid formation from 3-phosphoglyceric acid indicated the presence of phosphoglyceromutase, enolase and pyruvic phosphokinase. Arsenite was added to prevent further metabolism of pyruvate and the identity of this product was confirmed by paper chromatography. 


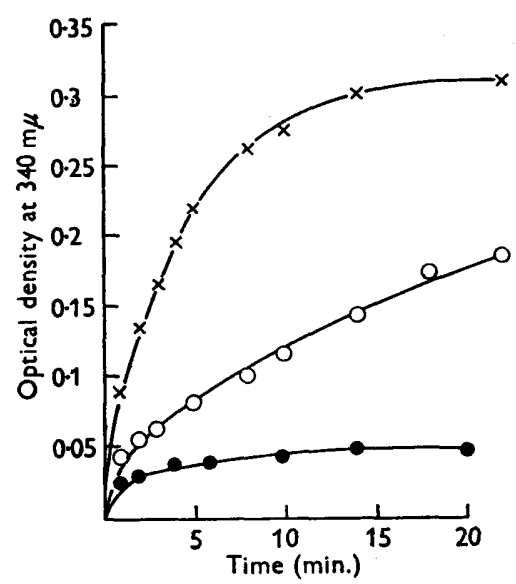

Fig. 2

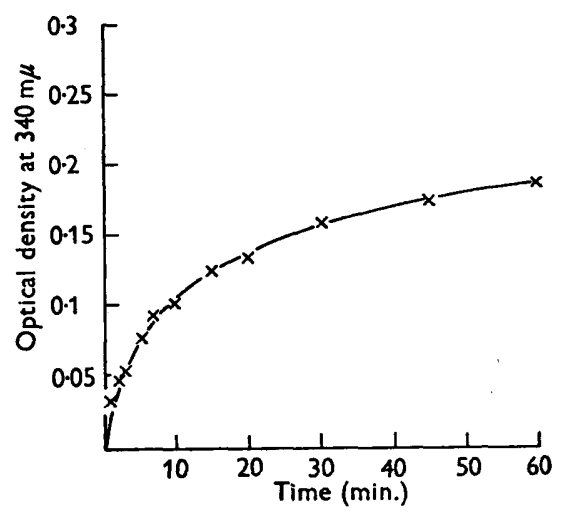

Fig. 3

Fig. 2. Phosphoglucomutase activity. Additions : $0.5 \mathrm{ml}$. aq. enzyme extract (1.12 mg N/ $\mathrm{ml}.) ; \quad 150 \mu \mathrm{g}$. TPN; $0.018 \mathrm{M}-\mathrm{MnCl}_{2} .4 \mathrm{H}_{2} \mathrm{O} \quad(0.1 \mathrm{ml}$.); $0.01 \mathrm{M}$-glucose-6-phosphate $(0.1 \mathrm{ml}.) ; 0.01 \mathrm{M}$-glucose-1-phosphate $(0.1 \mathrm{ml}$.); $0.05 \mathrm{M}$-(2-amino-2-hydroxymethylpropane-1:3-diol) buffer (pH 7.4; $1.8 \mathrm{ml}$.); water to $3 \mathrm{mI}$. TPN added at zero time. $x=$ glucose-6-phosphate; $O=$ glucose-1-phosphate; $O=$ endogenous.

Fig. 3. Glyceraldehyde phosphate dehydrogenase activity. Additions: 0.2 ml. aq. enzyme extract (0.769 mg. N/ml.); 2.0 mg. DPN; 0.03 M-fructose-1:6-diphosphate (0.1 ml.); 0.05 $\mathrm{m}$-tris buffer (pH 8.2; $2.0 \mathrm{ml}$.); $0.15 \mathrm{M}-\mathrm{Na}$ arsenate $(0.1 \mathrm{ml}$.); $0.1 \mathrm{~m}-\mathrm{NaF}$ (0.1 ml.); $0.09 \mathrm{M}$-cysteine hydrochloride $(0.1 \mathrm{ml}$.); $1 \mathrm{mg}$. crystalline aldolase; water to $3 \mathrm{ml}$. Incubation at $35^{\circ}$ with aldolase for $30 \mathrm{~min}$. before addition of DPN. No activity on omission of arsenate and cysteine, or on replacing DPN by TPN.

\section{Enzymes of the tricarboxylic acid cycle}

Attempts to demonstrate the pyruvic acid and $\alpha$-oxoglutaric acid oxidase systems in the cell-free extracts met with poor success. It was known from previous work that the intact mycelium showed no response in respiratory activity to added substrates and that mycelial dispersions showed very low activity. The cell-free extracts in the presence of the normal co-factors showed some endogenous oxygen uptake but either a low or negligible response to added pyruvate or $\alpha$-oxo-glutarate. Thus the evidence for these systems, rests principally upon the accumulation of the $\alpha$-keto acids in the presence of arsenite when mycelial pads were incubated alone or in the presence of glucose (Chattaway et al. 1956).

The cell-free extracts showed ability to oxidize succinate as determined by oxygen uptake; thus $80 \mu$ mole sodium succinate with $2.0 \mathrm{ml}$. enzyme preparation $(2.5 \mathrm{mg} . \mathrm{N} / \mathrm{ml}$.) in $\mathbf{0 . 5} \mathrm{M}$-phosphate buffer ( $\mathrm{pH} \mathrm{7.4}$; total vol. $3.0 \mathrm{ml}$.) showed an oxygen uptake of $14 \cdot 9 \mu \mathrm{l} . \mathrm{O}_{2} / \mathrm{mg}$. $\mathrm{N} / \mathrm{hr}$. after allowing for the endogenous uptake.

Aconitase activity was shown by a decrease in optical density at $240 \mathrm{~m} \mu$ during incubation and fumarase by following optical density changes at $300 \mathrm{~m} \mu$; the results are shown in Fig. 4.

Isocitric dehydrogenase was readily demonstrated in the presence of TPN; there was no activity with DPN. A requirement for a divalent metal was found 
following dialysis of the extract. This was best satisfied by manganese; magnesium showed a lower activity (Table 1).

Malic dehydrogenase was demonstrated and was DPN specific. By using Straub's method a very rapid endogenous reduction of cytochrome $c$ was found but after dialysis against tris buffer $(\mathrm{pH} 7 \cdot 4)$ this was removed and the enzyme activity satisfactorily measured (Fig. 5).

\section{Enzymes of the hexosemonophosphate pathway}

Evidence for the presence of the hexosemonophosphate pathway was provided by finding in the mycelial extracts glucose-6-phosphate and 6-phosphogluconate dehydrogenases (Fig. 6), and the demonstration of pentose

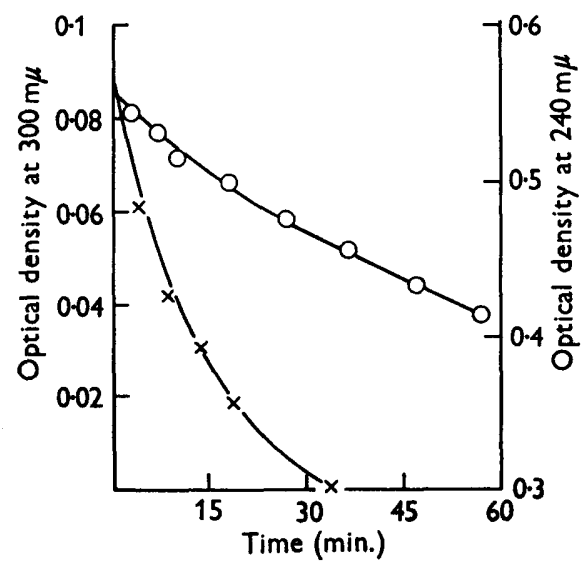

Fig. 4

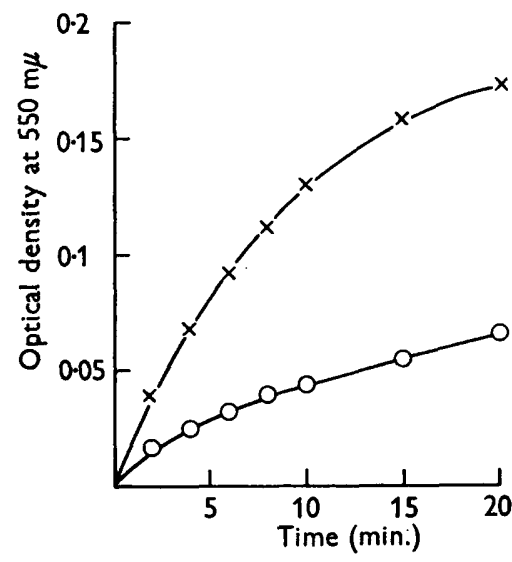

Fig. 5

Fig. 4. Aconitase and fumarase activity. Additions: $3 \mathrm{ml}$. enzyme extract in $0.05 \mathrm{~m}$ phosphate buffer (pH 7.4); 0.1 M-cis-aconitic acid or fumaric acid (0.1 ml.); final volume $3.5 \mathrm{ml}$. with water. Boiled controls showed no activity. $\times=$ fumarase; $0=$ aconitase.

Fig. 5. Malic dehydrogenase activity. Additions : $3.0 \mathrm{ml}$. dialysed enzyme extract (276 $\mu \mathrm{g} . \mathrm{N} /$ ml.) in 0.05 M-tris buffer (pH 7.4); $600 \mu \mathrm{g}$. cytochrome $c ; 0.1 \mathrm{M}-\mathrm{KCN}(0.1 \mathrm{ml}$.); 0.5 ML-malic acid (0.2 ml.); $166 \mu \mathrm{g}$. DPN; water to $3.5 \mathrm{ml} . \times=$ complete system; $O=$ without substrate.

\section{Table 1. Isocitric dehydrogenase activity}

3.0 ml. enzyme extract (307 $\mu \mathrm{g} . \mathrm{N} / \mathrm{ml}$.) in $0.05 \mathrm{M}$-tris buffer (pH 7.4); $150 \mu \mathrm{g}$. TPN in each tube. Dialysis was for $13 \mathrm{hr}$. against 1 l. tris buffer $(\mathrm{pH} 7 \cdot 4)$ at $4^{\circ}$ with slow rotation. Reduction of TPN is recorded by increase in optical density (o.D.) at $340 \mathrm{~m} \mu$.

\begin{tabular}{|c|c|c|c|c|}
\hline \multirow[b]{2}{*}{ Substrate } & \multirow[b]{2}{*}{$\underset{(\mu \mathrm{M})}{\mathrm{MnCl}_{2} \cdot 4 \mathrm{H}_{2} \mathrm{O}}$} & \multirow[b]{2}{*}{$\underset{(\mu \mathrm{M})}{\mathrm{MgCl}_{\mathbf{2}} \cdot \mathbf{6 H} \mathrm{H}_{\mathbf{2}} \mathrm{O}}$} & \multicolumn{2}{|c|}{$\begin{array}{c}\text { Optical density } 1-3 \mathrm{~min} \text {. after } \\
\text { addition of TPN } / \mathrm{mg} . \mathbf{N}\end{array}$} \\
\hline & & & Before dialysis & After dialysis \\
\hline - & - & - & 0.039 & $0 \cdot 002$ \\
\hline- & $1 \cdot 8$ & 一 & 一 & $0 \cdot 021$ \\
\hline- & - & $\mathbf{2 \cdot 0}$ & - & 0.008 \\
\hline \multirow{2}{*}{$\begin{array}{c}\text { Isocitrate } \\
(0.6 \mu \mathrm{M})\end{array}$} & - & - & $0 \cdot 201$ & 0.045 \\
\hline & $1 \cdot 8$ & $\overline{2 \cdot 0}$ & $\begin{array}{l}0 \cdot 188 \\
0 \cdot 184\end{array}$ & $\begin{array}{l}0 \cdot 114 \\
0 \cdot 047\end{array}$ \\
\hline
\end{tabular}

$4 I$

G. Microb. xxII 
formation as a result of their action (Table 2). The maximum value of pentose found represents a $20 \%$ conversion of the substrate; the true figure may well be higher since the pentose was probably further metabolized.

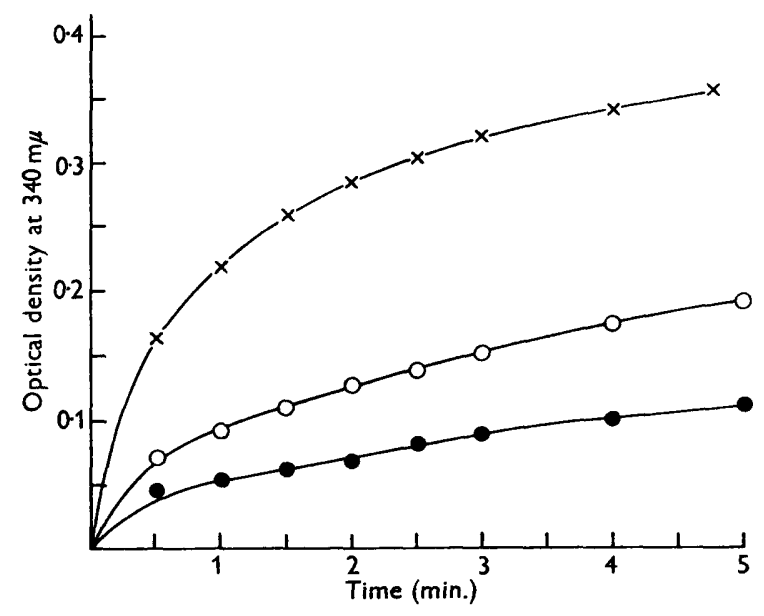

Fig. 6. Glucose-6-phosphate and 6-phosphogluconate dehydrogenases. Additions: $3.0 \mathrm{ml}$. enzyme extract (150 $\mu \mathrm{g} . \mathrm{N} / \mathrm{ml}$.) in tris buffer (pH 7.4); $150 \mu \mathrm{g}$. TPN; $1.0 \mu \mathrm{M}$-glucose6-phosphate or 6-phosphogluconate; $1.8 \mu \mathrm{M}-\mathrm{MnCl}_{2} \cdot 4 \mathrm{H}_{2} \mathrm{O}$; water to $3.8 \mathrm{ml}$. TPN added at zero time. $x=$ glucose-6-phosphate; $O=6$-phosphogluconate; $O=$ endogenous.

Table 2. Pentose formation from glucose-6-phosphate

$15.0 \mathrm{ml}$. enzyme extract $(1.31 \mathrm{mg}$. $\mathrm{N} / \mathrm{ml}$.) in $0.01 \mathrm{M}$-acetate buffer $(\mathrm{pH} \mathrm{6.4}) ; 0.01 \mathrm{M}$ glucose-6-phosphate (3.0 ml.); 3.0 $\mathrm{mg}$. TPN; water to $20 \mathrm{ml}$. Samples $(2.0 \mathrm{ml}$.) were taken at intervals during incubation at $35^{\circ}$ and added to $2.0 \mathrm{ml} .10 \%(\mathrm{w} / \mathrm{v})$ trichloracetic acid, centrifuged and pentose estimated in the supernatant. A control flask without substrate gave no increase in orcinol colour above that obtained from the original extract + TPN.

$\begin{array}{cc}\begin{array}{c}\text { Time of } \\ \text { incubation } \\ \text { (min.) }\end{array} & \begin{array}{c}\text { Pentose formed } \\ (\mu \mathrm{g} .)\end{array} \\ 3 & 280 \\ 5 & 720 \\ 15 & 920 \\ 30 & 960 \\ 45 & 800\end{array}$

\section{DISCUSSION}

The above results, together with previous work on the effect of metabolic inhibitors on the endogenous respiration of intact mycelium and on the accumulation of pyruvic and $\alpha$-oxoglutaric acids in replacement cultures, provide strong evidence for the presence in Microsporum canis of the Embden-Meyerhof pathway for glucose metabolism and for the tricarboxylic acid cycle. Evidence for their quantitative significance in the intact fungus is not, however, provided; it will depend upon work with isotopically-labelled substrates. 
Certainly the presence of glucose-6-phosphate and 6-phosphogluconate dehydrogenases and the accumulation of appreciable amounts of pentose from these substrates indicates that an alternative pathway is operative and may well account for an appreciable proportion of the carbohydrate metabolized.

Jensen et al. (1957) drew attention to the apparent specificity for TPN shown by many of the dehydrogenases of Trichophyton mentagrophytes and this has also been found with Microsporum canis for the isocitric, glucose6-phosphate and 6-phosphogluconate dehydrogenases. However, extracts which contained these enzymes failed to show dehydrogenase activity with either TPN or DPN for ethanol and lactate. The nature of the endogenous substrate which promoted considerable TPN reduction is unknown; it may be polysaccharide in nature since it is not dialysable, and the loss of endogenous TPN reduction found on dialysis was restored by the addition of manganese. That DPN does function in these fungi is shown by its necessity for glyceraldehyde-3-phosphate dehydrogenase and the malic dehydrogenase in $M$. canis and the finding that it was essential for the former enzyme in $T$. mentagrophytes. (Jensen et al. 1957). There was no evidence for a TPN-specific glyceraldehyde-3-phosphate dehydrogenase such as has been described in green leaves (Arnon, Rosenberg \& Whatley, 1954). Whether TPN utilization has any special significance in the dermatophytes will depend in part on the relative quantitative importance of the various possible routes of carbohydrate metabolism.

We wish to thank the Agricultural Research Council for a maintenance grant to one of us (C.C.T.) and Dr E. A. Dawes for a gift of 6-phosphogluconic acid.

\section{REFERENCES}

Arnon, D. I., Rosenberg, L. L. \& Whatley, F. R. (1954). A new glyceraldehyde phosphate dehydrogenase from photosynthetic tissue. Nature, Lond. 173, 1132.

Chattaway, F. W., Thompson, C. C. \& Barlow, A. J. E. (1954). Enzymes of Microsporum canis. Biochim. biophys. Acta, 14, 583.

Chattaway, F. W., Thompson, C. C. \& Barlow, A. J. E. (1956). The action of inhibitors on dermatophytes. Biochem. $J .63,648$.

Friedmann, T. E. \& Haugen, G. E. (1943). Pyruvic acid. II. The determination of keto acids in blood and urine. J. biol. Chem. 147, 415.

Jensen, E. M., Altschuller, H. \& Bard, R. C. (1957). Glycolytic and respiratory enzymes of Trichophyton mentagrophytes. J. Bact. 74, 656 .

MARKHAM, R. (1942). A steam distillation apparatus suitable for micro-Kjeldahl analysis. Biochem. J. 36, 790.

Mejbaum, W. (1939). Über die Bestimmung kleiner Pentosemengen, insbesondere in Derivaten der Adenylsäure. Hoppe-Seyl. Z. 258, 117.

Melton, F. M. (1951). The effect of various substances on the oxygen uptake of Microsporum canis grown in submerged culture. J. Invest. Derm. 17, 27.

Moore, W. I. \& MASON, B. (1951). Blender for preparation of mycelial inocula. J. gen. Microbiol. 5, 516.

Nickerson, W. J. \& Chadwick, J. B. (1946). On the respiration of dermatophytes. Arch. Biochem. 10, 81.

RACKER, E. (1950). Spectrophotometric measurements of the enzymatic formation of fumaric and cis-aconitic acids. Biochim. biophys. Acta, 4, 211. 
Siblex, J. A. \& LeHNinger, A. L. (1949). Determination of aldolase in animal tissues. J. biol. Chem. 177, 859.

Sin, C. J. \& Knight, S. G. (1956). Carbohydrate metabolism of Penicillium chrysogenum. J. Bact. 72, 694 .

SuerN, M. W. (1955). In Methods in Encymology, 1, p. 299. New York: Academic Press Inc.

Straub, F. B. (1942). Reinigung der Apfelsäuredehydrase und die Bedeutung der Zellstruktur in der Apfelsäuredehydrierung. Hoppe-Seyl. Z. 275, 63.

(Received 1 October 1959) 